Onkologie 1983;6:211

\title{
Inhalt, Vol. 6, No. 5, 1983
}

Contents

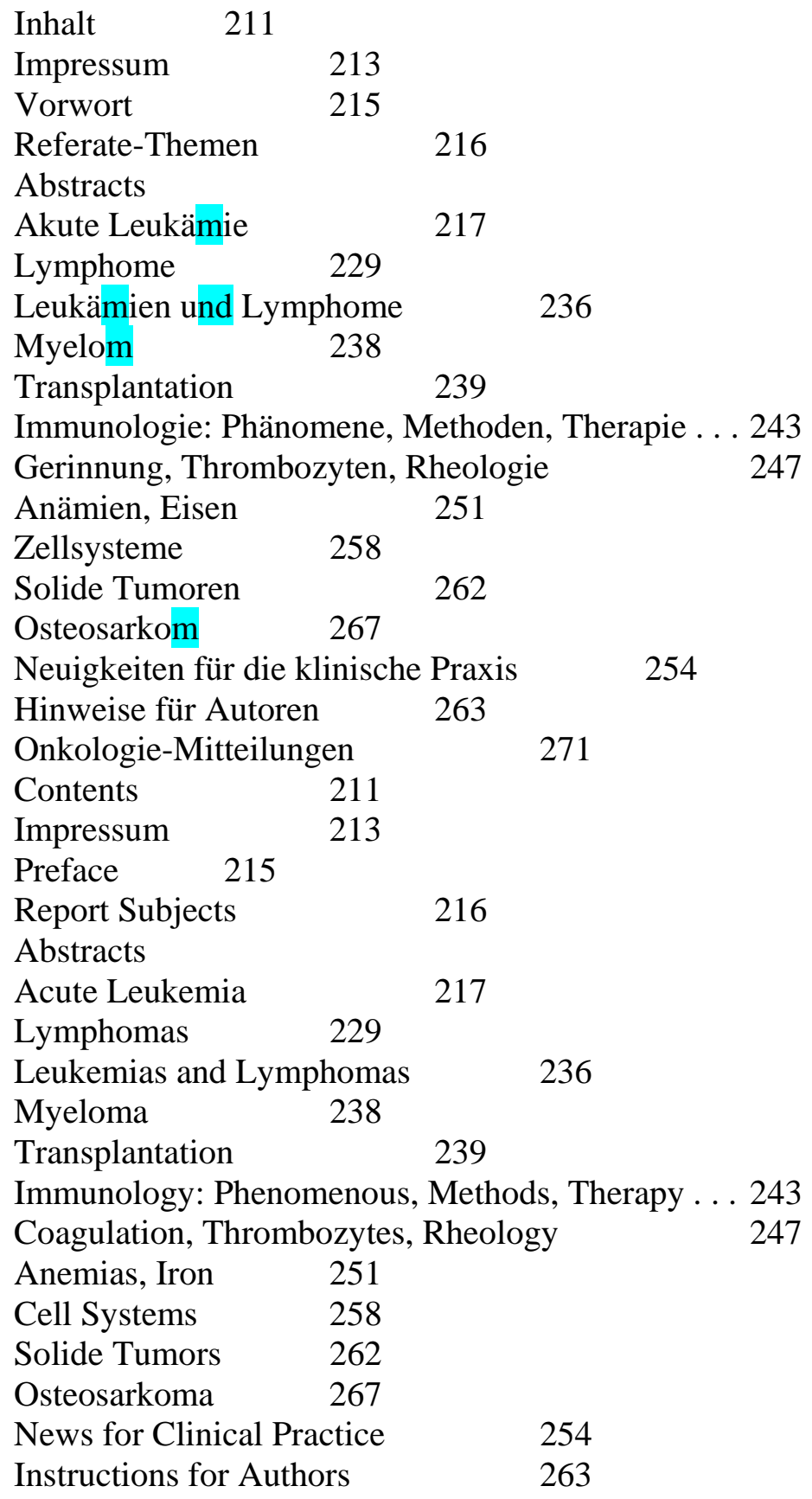


Oncology Communications

271

Beilagen-Hinweis: Einem Teil dieser Ausgabe liegt ein Prospekt vom Thieme-Verlag Stuttgart bei. Wir bitten um Beachtung.

Bibliographischer Hinweis: Inhaltsverzeichnisse dieser Zeitschrift erscheinen regelmäßig in current contents ${ }^{\circledR}$ sowie in anderen bibliographischen Diensten. 